\title{
Mobility and livestock mortality in communally used pastoral areas: the impact of the 2005-2006 drought on livestock mortality in Maasailand
}

\author{
David Nkedianye ${ }^{1,2^{*}}$, Jan de Leeuw ${ }^{1}$, Joseph O Ogutu ${ }^{1,3}$, Mohammed Y Said ${ }^{1}$, Terra L Saidimu ${ }^{4}$, Shem C Kifugo ${ }^{1}$, \\ Dickson S Kaelo ${ }^{1}$ and Robin S Reid ${ }^{5}$
}

* Correspondence: nkedav@yahoo. com

${ }^{1}$ International Livestock Research Institute, P.O. Box 3070900100 , Nairobi, Kenya

Full list of author information is available at the end of the article

\begin{abstract}
There is consensus that pastoral mobility is beneficial for both pastoralists and the environment. However, rapid change arising from multiple factors, including landscape fragmentation, sedentarization, and demographic drivers might affect the effectiveness of this pastoral coping strategy in times of drought. We investigate livestock mortality rates following the 2005 drought in four areas in Maasailand: the Maasai Mara, the Kitengela plains, the Amboseli, and the Simanjiro plains. The main aim was to assess the mortality of resident livestock in relation to incoming livestock during the drought. Contrary to our expectations, livestock mortality rates were significantly higher (43\%) in Kitengela, which experienced above-average rainfall, compared to the other three areas which had below-average rainfall yet experienced mortality rates between $14 \%$ and $30 \%$. Two processes might explain this surprisingly high mortality rate. Firstly, the immigration of large numbers of livestock from drought-stricken areas into the highly fragmented Kitengela area increased stocking density, which worsened the shortage of forage and water. Secondly, the more market-oriented but less drought-resistant livestock breeds in Kitengela form another explanation for the increased mortality. These observations suggest that pastoral mobility may lead to greater sensitivity to drought especially in fragmented areas where more market-oriented but less drought-resistant livestock breeds are introduced. We argue that in such areas, there is a crucial need to adopt practices that simultaneously minimize land fragmentation and enhance pastoral mobility and access to information on improved livestock breeds and markets.
\end{abstract}

Keywords: drought, East Africa, mobility, livestock mortality, improved breeds, fragmentation

\section{Background}

Pastoral livestock production, the dominant land use in the arid and semi-arid lands of Africa, provides a livelihood to millions of people. Traditionally, pastoral societies have been relatively wealthy and even today the livelihoods of pastoralists tend to compare well with others in years of good rainfall. The arid lands of Africa experience frequently recurring droughts; however, these have significant effects on livestock and pastoral livelihoods alike (Zamani et al. 2006; Le Houerou 1996; Oba and Lusigi 1987).

\section{Springer}

(c) 2011 Nkedianye et al; licensee Springer. This is an Open Access article distributed under the terms of the Creative Commons Attribution License (http://creativecommons.org/licenses/by/2.0), which permits unrestricted use, distribution, and reproduction in any medium, provided the original work is properly cited. 
Pastoral societies were considered resilient to drought as they traditionally recovered during years of better rainfall. Recently, this perception of pastoral resilience is under increasing scrutiny as social, economic, and environmental factors exert more pressure in these systems. In some areas, such as the horn of Africa, sequences of recurring droughts push pastoralists out of livestock and into poverty and food aid dependency (Fratkin 2001; Campbell 1999; Spencer 1974).

What caused this weakening of pastoral resilience? Traditionally, a number of strategies were used to prevent or alleviate the effects of drought. Firstly, pastoralists maintained large herds to ensure that sufficient animals would survive to rebuild the herds after the drought (McPeak 2005). In many areas, the resilience provided by large herds has been greatly eroded because, due to demographic growth, per capita herd size has reduced (Lamprey and Reid 2004; Sindiga 1984), hence increasing vulnerability to drought. The loss of pastoral lands, which were used as drought refuges to agriculture, conservation (Homewood et al. 2009; Brockington 2005; McCabe 2003) and urbanization (Behnke 2008), and sedentarization from a formerly semi-nomadic lifestyle and the associated land fragmentation and intensification of land use further reduced resilience. Secondly, pastoralists reduce risk while spreading their animals over herds of relatives and maintain social institutions to support those affected by drought. These strategies are, however, under increasing pressure due to weakening of the social networks which once supported them.

Pastoral mobility is probably the oldest described drought coping strategy, as in Genesis 47:3-4 (The Bible 2009) where the Israelites explain their migration into Egypt before the Pharaoh as follows: "We have come to live here awhile, because the famine is severe in Canaan and your servants' flocks have no pasture. So now, please let your servants settle in Goshen." During the colonial period in East Africa at the beginning of the twentieth century, the idea that mobility has benefits gained support when the colonial administration in Kenya and Tanzania tried to disrupt pastoral mobility (Borjeson et al. 2008; Hughes 2006; Hodgson 2001; Rutten 1992).

Today, there is consensus regarding the social benefits of pastoral mobility, and the "blessings of pastoral mobility hypothesis" has thus attained the status of a paradigm. Although it is doubtless that mobility has been and will continue being helpful to pastoralists, the paradigm is mainly built, on a mixture of deductive argument and positive experiences from the past.

One problem of the blessings of pastoral mobility paradigm is that it does not highlight the costs of mobility, especially to resident communities. It is obvious that herdsmen, when confronted with drought, may benefit while moving their livestock to greener areas to reduce the mortality of their herd. The paradigm does not consider the negative social impacts for those inhabiting the lands receiving the hungry herds. That was probably also irrelevant in biblical times, as there was sufficient space. Similarly, following the rinderpest epidemic and depopulation in the 1890s (Rutten 1992; Talbot 1972) there must have been ample space in the rangelands in the Maasailand of the early twentieth century. Hence, competition with resident herds was unlikely at that time.

The situation is different today. In Maasailand, there is no more "no man's land" and little if any underutilized land. Today, pastoral mobility as a strategy to escape drought, means moving into lands utilized by others and often to far-flung areas. Such 
protracted movements and immigration into commonly used lands increases competition for forage and water resources (Hardin 1968) and the risk of contracting diseases, a situation that will affect the body condition of resident and immigrant livestock alike. Thus far, there has been no study addressing the benefits of pastoral mobility under conditions of intensifying utilization of rangeland resources.

In this study, we investigated mortality rates recorded during the 2005-2006 drought among 396 households in four areas of East African Maasailand. Three out of the four areas experienced below-average rainfall while the fourth had above-average rainfall. Pastoral mobility resulted in a significant influx of livestock in the latter site, but not in the first three sites. This contrast between the four sites enabled us to compare mortality rates among drought-affected and non-drought-affected sites, in the expectation that the non-drought-affected site would reveal lower mortality rates.

\section{Materials and methods}

\section{Study area}

The research was undertaken in four sites across Maasailand (Figure 1), three in Kenya (Mara, Kitengela, and Amboseli) and one in Tanzania (Simanjiro). Table 1 describes

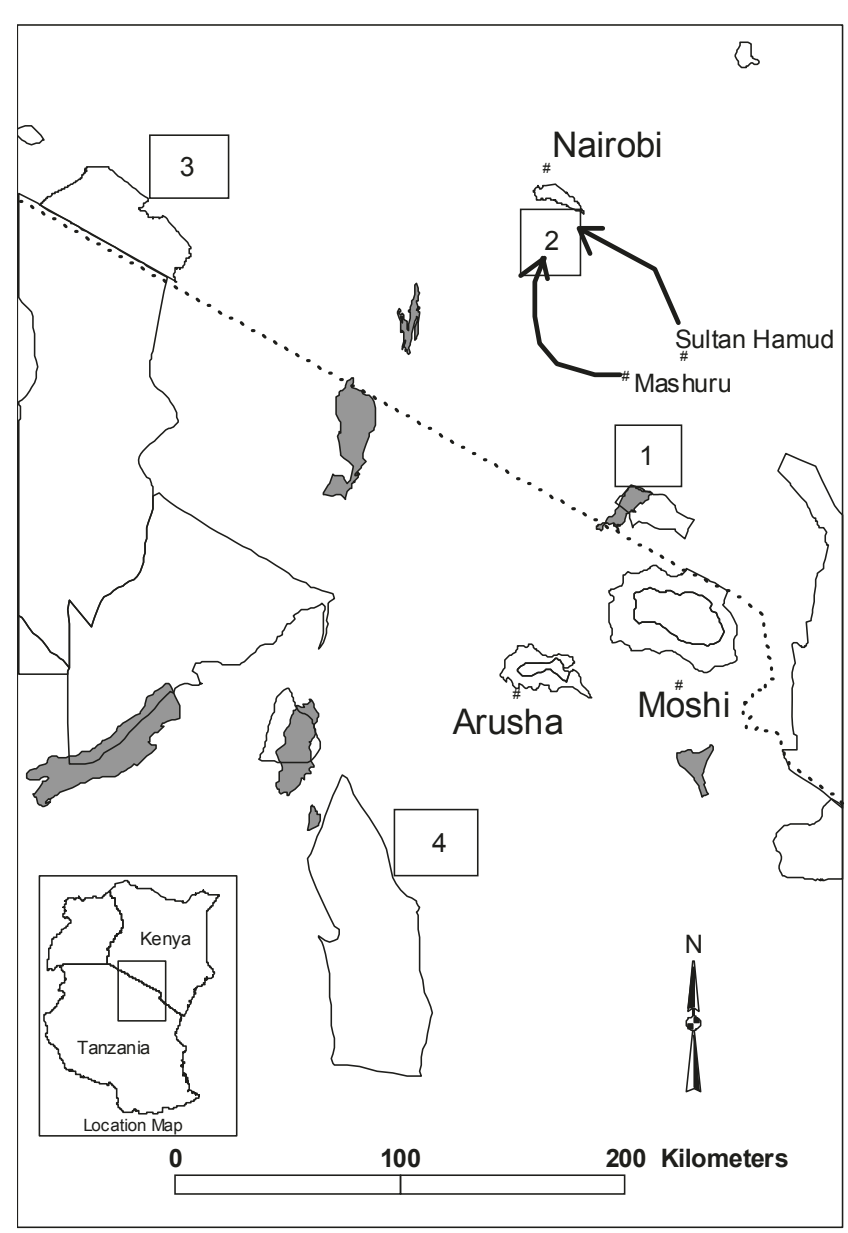

Figure 1 Map of the study areas showing the four study sites. 1, Amboseli; 2, Kitengela; 3, Mara; and 4, Simanjiro). Arrows indicate migration of livestock towards the Kitengela area, broken line indicates International boundary. 
Table 1 Characterization of the four study sites

\begin{tabular}{|c|c|c|c|c|}
\hline Site & $\begin{array}{l}\text { Rainfall } \\
(\mathrm{mm})\end{array}$ & Land tenure & Land use & Land cover (\%) \\
\hline Amboseli $\left(8,400 \mathrm{~km}^{2}\right)$ & $\begin{array}{l}\text { 350-600 } \\
\text { (Bimodal) }\end{array}$ & Group ranches. Private & Livestock, wildlife, agriculture and horticulture & G, 34; S, 5; WB, 60; W, 1 \\
\hline Kitengela $(390$ km²) & $\begin{array}{l}\text { 440-900 } \\
\text { (Bimodal) }\end{array}$ & Privately owned, subdivided from 1986 & Livestock, wildlife, agriculture and horticulture & G, 91; S, 7; WB, 1; urban areas, 1 \\
\hline Maasai Mara $\left(6,500 \mathrm{~km}^{2}\right)$ & $\begin{array}{l}\text { 400-1200 } \\
\text { (Bimodal) }\end{array}$ & Privately owned, subdivided from 2000 & Livestock, wildlife, little agriculture & Grassland, 60; S, 34; WB, 6 \\
\hline Simanjiro 384.2 & $\begin{array}{l}\text { 650-900 } \\
\text { (Bimodal) }\end{array}$ & Government owned, village control & Livestock, wildlife, expanding agriculture & $G, 62 ; W B, 28 ; C, 10$ \\
\hline
\end{tabular}


the climate, vegetation and land tenure, and use of the four sites. Rainfall is bimodal with the long rains (Kenya Meteorological Department 2008) being heavier and more reliable in Kitengela, Simanjiro, and the Maasai Mara (Ogutu et al. 2007; Njoka 1979; Pratt et al. 1966) and the short rains in October-December being more pronounced in Amboseli (De Leeuw 1991). The El Niño-Southern Oscillation causes quasi-cyclicity in rainfall in Maasailand (Ogutu et al. 2007; Mworia and Kinyamario 2008) and is most pronounced during the October-December season (Ogallo et al. 1988).

There is regional variation in the distribution of breeds of cattle, sheep, and goats, which reflects choices made by pastoralists in response to prevailing market demands, climatic, and disease-related constraints. Traditional breeds prevail in most areas due to constraints such as Trypanosomosis in the Mara and parts of Simanjiro and the dry and hot conditions in the Amboseli. More market-oriented breeds such as Dorper Sheep and Boran/Sahiwal and their crossbreeds have been introduced in the Kitengela plains (Table 2).

\section{Livestock mortality survey}

Livestock mortality surveys were conducted by locally recruited enumerators in one hundred randomly selected households per study site during the 3 months (May to July 2006) immediately after the drought of March-April 2006. These multi-site simultaneous surveys are rarely done but were possible to conduct because the senior author of the paper and the enumerators were all native Maa-language speakers. The enumerators, who all had an "ordinary level" certificate in formal education and prior surveying experience, were thoroughly trained before the survey. Livestock losses were recorded by livestock species by household and per site. Livestock numbers were converted into Tropical Livestock Units (TLU) by multiplying total numbers of cattle by $0.72 \mathrm{~kg}$, while sheep and goats (shoats) numbers were multiplied by $0.17 \mathrm{~kg}$ (Radeny et al. 2007). A global positioning system (GPS) was used to fix the location of the homesteads.

\section{Statistical analysis}

Annual rainfall data from multiple weather stations in each of the four areas (seven in Kitengela, nine in the Mara, eight in Amboseli, and five in Simanjiro) were obtained from the meteorological departments of Kenya and Tanzania, and averaged to one annual rainfall value for each study area to filter out spatial variation. We analyzed the temporal variation in annual rainfall using standardized anomalies $\left(z=\left(x_{t}-\bar{x}\right) / \sigma\right)$, where $x_{\mathrm{t}}$ is the rainfall component in year $t, \bar{x}$ is the mean, and $\sigma$ is the standard deviation of the rainfall component during 1960-2007 (Ogutu et al. 2007) (Figure 2).

We analyzed the variation in the proportion of livestock that died across the four sites during the drought of 2005-2006, and compared the results across the four sites to establish the effects of drought on livestock mortality. The analysis was performed at an aggregated livestock (cattle, sheep, and goats) level expressed in TLU, as well as for the three species separately.

We used a generalized linear model with mortality rate as the dependent and site as the independent categorical variable, to analyze differences in livestock mortality rates among the four sites. Averaging of mortality over the households would lead to a 
Table 2 Description of the main livestock breeds in the four study areas

\section{Site}

Amboseli

Kitengela

Mara

Simanjiro Cattle

Maasai Zebu

Boran, Sahiwal crosses, Maasai Zebu

Maasai Zebu

Maasai Zebu
Sheep

Blackhead Somali, Red Maasai

Dorper, mixed Dorper $\times$ Red Maasai

Red Maasai

Red Maasai, Blackhead Somali
Goats

Mixed: Galla, Small E. African

Mixed: Galla, Small E.African

Mixed: Small E. African, Maasai

Mixed: Small E. African, Maasa 


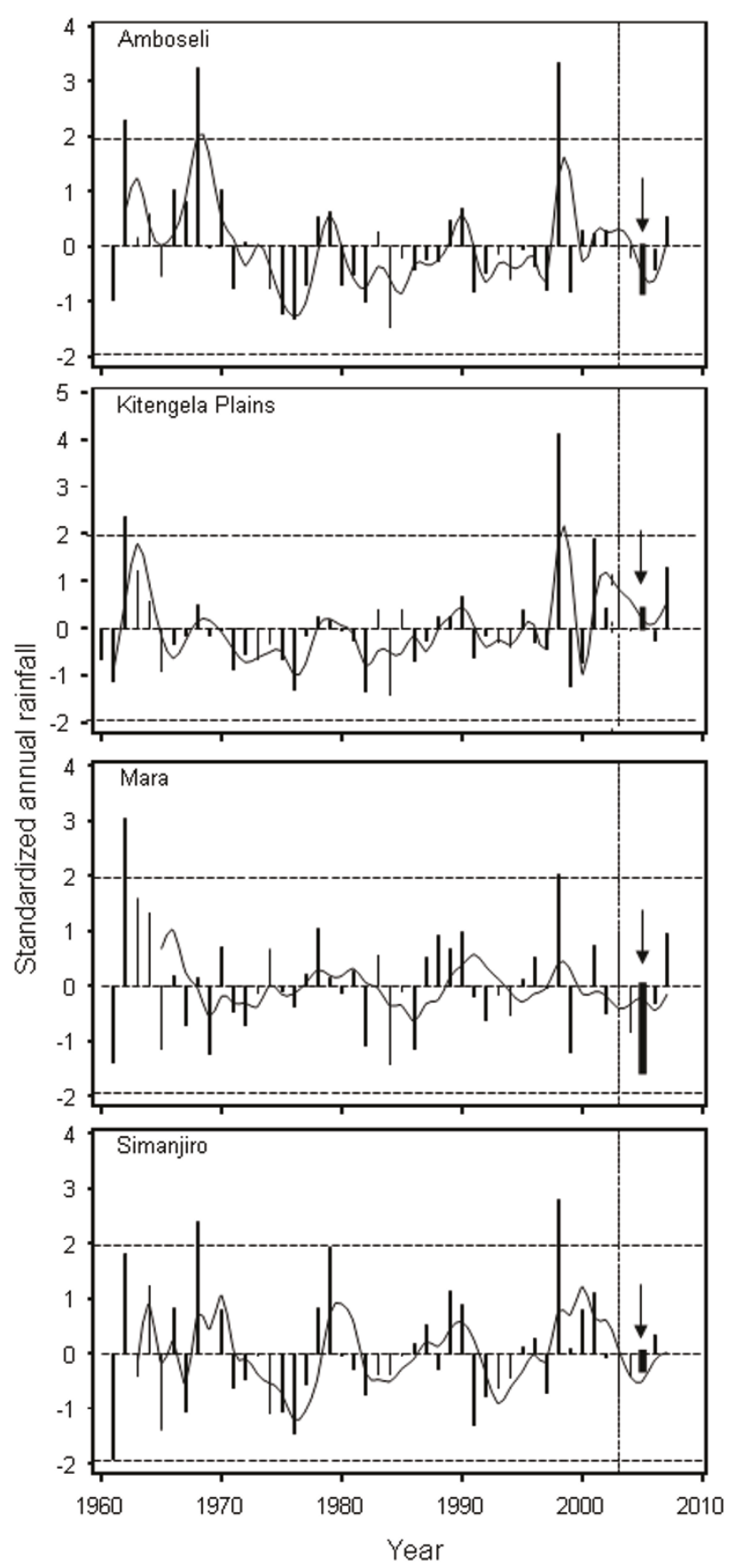

Figure 2 Standardized anomalies from the long-term mean (1961-2007) of annual rainfall for the four study sites. With an interpolation based on the 3-year running mean revealing quasi-cyclicity in the rainfall data. Dashed horizontal lines are 2 standard deviations (1.96) from the average (0). The vertical dashed lines identify the year 2003 as a reference year, while arrows point at the year 2005.

biased estimate of the overall mortality, because there were significant differences in herd size between households. We therefore weighted the cases as follows:

$$
W_{i, j}=\frac{x_{i, j}}{\bar{x}_{i}}
$$


Where $w_{i, j}$ and $x_{i, j}$ represent the weight and herd size (in TLU) for the $j$ th household at the $i$ th site, respectively, and $\bar{x}_{i}$ the average herd size at the $i$ th site.

\section{Financial loss caused by drought}

We also estimated the monetary value of the loss of livestock per household. For this, we multiplied for each of the four areas the average numbers of cattle, sheep, and goats lost per household by the monetary value of each of these three species based on prevailing prices at the local sale points for the period before the onset of the drought. An average price of Ksh 18,000 and Ksh 15,000 was used for cattle in Kitengela and the other areas, respectively, while an average price of Ksh 2,000 and Ksh 1,500 was used for sheep and goats in Kitengela and the other areas, respectively (Table 3).

\section{Narrative}

The analysis revealed surprising mortality rates in Kitengela. To explain this, we compiled a narrative of what happened in Kitengela during the drought and in the preceding year (Table 4). The narrative describes the movements and the conditions of the immigrant and resident livestock as well as the condition of the rangelands. It is based on the recollection of the lead author, who lived and owned livestock in Kitengela during this period. The narrative was cross-checked with concurrent experiences of a peer group of livestock owners and traders of different ages who lived in the wider Kitengela area. Where appropriate, reference is made to their experiences.

\section{Results}

Figure 2 describes the variation in standardized annual rainfall for the 47-year period during 1961-2007. The figure reveals that Kitengela received above-average rainfall in 2005, while rainfall in Amboseli, Simanjiro, and the Mara was below average. Hence

Table 3 Livestock mortality in percentage, and the estimated loss in monetary value by livestock species

\begin{tabular}{lcccccc}
\hline Site & Class & Total died & \% died & CostKsh-000 & Average Ksh per household & US\$ per household \\
\hline Amboseli & Cattle & 2,158 & 32 & 32,370 & 323,700 & 4,465 \\
& Sheep & 1,665 & 27 & 2,498 & 24,975 & 345 \\
& Goats & 891 & 24 & 1,337 & 13,365 & 134 \\
& Total & & & 36,204 & 362,040 & 4,994 \\
Kitengela & Cattle & 2,149 & 45 & 38,682 & 386,820 & 5,335 \\
& Sheep & 4,586 & 47 & 9,172 & 91,720 & 1265 \\
& Goats & 1,095 & 35 & 2,190 & 21,900 & 302 \\
& Total & & & 50,044 & 500,440 & 6,903 \\
Mara & Cattle & 2,793 & 29 & 41,895 & 418,950 & 5,779 \\
& Sheep & 2,836 & 21 & 4,254 & 42,540 & 587 \\
& Goats & 559 & 22 & 839 & 8,385 & 118 \\
& Total & & & 46,988 & 469,875 & 6,481 \\
Simanjiro & Cattle & 1,091 & 13 & 16,365 & 163,650 & 2,257 \\
& Sheep & 451 & 11 & 677 & 1,765 & 93
\end{tabular}

Livestock mortality (in absolute numbers) and as percent of initial numbers, the estimated loss in monetary value by livestock species per site-(for 100 households sampled). ${ }^{a}$ Absolute numbers for shoats multiplied by 2,000 for Kitengela and 18,000 for cattle. For all other sites, the total died is multiplied by 1,500 for shoats and 15,000 for cattle. The differences in prices among sites are based on general differences in weights for different livestock breeds. 
Table 4 Narrative of the condition of the rangelands and the movements of resident and immigrant herds

\begin{tabular}{|c|c|}
\hline Period & Event(s) \\
\hline 2004 March-May & Average long rains \\
\hline 2004 June & $\begin{array}{l}\text { First immigrant herds arriving from drought-stricken areas of Sultan Hamud and Mashuru } \\
\text { in the South-east }\end{array}$ \\
\hline $\begin{array}{l}2004 \text { October- } \\
\text { December }\end{array}$ & Good short rains \\
\hline 2005 March-May & Above-average long rains, good productivity of rangelands \\
\hline 2005 May-June & More immigrant livestock arriving, stocking density at least twice the normal \\
\hline 2005 August & All grass depleted \\
\hline $\begin{array}{l}2005 \text { October- } \\
\text { November }\end{array}$ & Failure of short rains, severe competition between resident and immigrant herds \\
\hline 2005 December & Start of mortality, first among immigrant followed by resident herds \\
\hline $\begin{array}{l}2006 \text { February- } \\
\text { March }\end{array}$ & Peak mortality for all livestock \\
\hline 2006 March-April & $\begin{array}{l}\text { Onset of the rains, continued mortality of weakened livestock due to pneumonia and } \\
\text { other diseases }\end{array}$ \\
\hline
\end{tabular}

In the Kitengela area before and during the 2005-2006 drought.

from a meteorological perspective, three areas experienced a drought, while Kitengela did not. The figure, furthermore, reveals that Amboseli, Simanjiro, and the Mara also experienced drought in 2004, while Kitengela had close to normal rainfall.

There was a significant difference in mortality rates between the four sites (weighted ANOVA; $F_{3,390}=40.91 ; P<0.001$ ). A pair-wise multiple comparison adjusted for multiplicity using the Bonferoni correction revealed that all sites differed from each other (All $P \mathrm{~s}<0.001)$. However, the difference between Amboseli and the Mara was insignificant $(P=0.751)$. Surprisingly, Kitengela incurred the highest overall livestock mortality rate of $43 \%$. The Amboseli, Mara, and Simanjiro had mortality rates of 30\%, 26\%, and $14 \%$, respectively.

The level of mobility differed across the four sites depending on the available flexibility in space. In the three less fragmented sites most of the movement was within the general area. In the Kitengela site, most of the influx of livestock was from adjoining areas. Where mobility is limited, one would expect mortality rates to increase with the severity of drought. Figure 3 confirms such a pattern for the three sites affected by the drought. However, Kitengela forms an outlier because it has a much higher mortality than would be expected by the severity of drought alone, considering that the area experienced no drought. It is worth reiterating here that Kitengela had more extreme land fragmentation and more drought-sensitive livestock breeds.

During the interviews with herdsmen, we noted large numbers of immigrant livestock in the Kitengela plains in 2004-2005. These herds arrived from mid-2004 onwards, following failure of the long and short rains in Mashuuru and Sultan Hamud to the south-east of Kitengela (Table 4 and Figure 1). Most of the immigrant herds disappeared in the middle of 2005 after they had depleted the forage produced during the above-average long rains earlier that year. In the other three areas, there was internal migration, but no immigration of livestock.

Thus far, we considered herd mortality rates, which are the result of the combined mortality of sheep, goats, and cattle. The herd composition differed somewhat between the three areas (Figure 4) and the differences in mortality rates could thus reflect differences in herd composition. In all the sites, cattle contributed most to the overall 


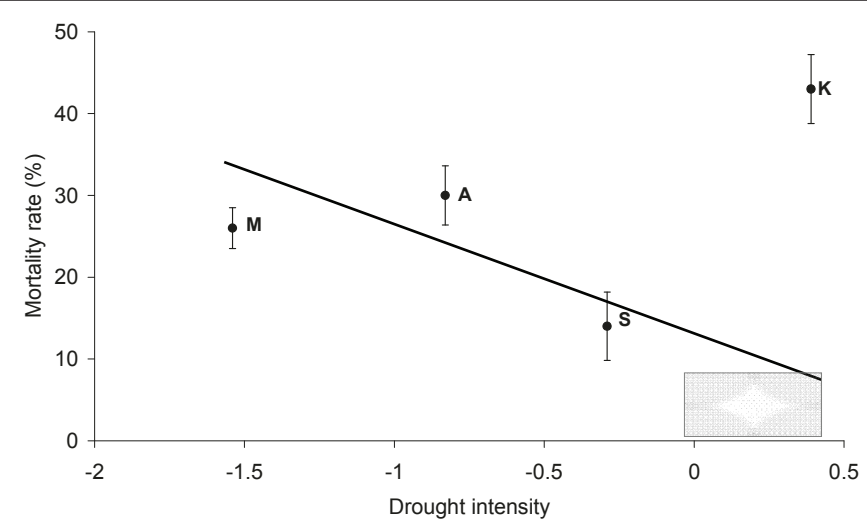

Figure 3 The relationship between herd mortality rate (percent) and the intensity of drought. This is based on the 2005 standardized anomalies (See Figure 2), for four sites. The regression line was fitted through three sites; discarding Kitengela which had unexpectedly high mortality. The shaded band at the bottom right reflects the range of mortality rates in non-drought years (Bekure, et al; 1991). M, Mara; A, Amboseli; S, Simanjiro; and K, Kitengela.

herd biomass (in TLU). There were some differences, with Amboseli, the Mara, and Simanjiro areas having $78 \%, 78 \%$, and $77 \%$ of herd biomass, respectively, composed of cattle. In Kitengela, cattle contributed somewhat less (62\%) to overall herd biomass, reflecting a relatively higher proportion of small stock. Table 3 reveals that most of the variation in herd mortality between the four areas was attributable to differences in mortality rates of the three livestock species between the four areas. Differences in herd composition contributed only marginally to the difference in herd mortality between the four areas.

Finally, there were marked differences in breeds raised in the four areas (Table 2). Traditional breeds prevailed in the Mara, Amboseli, and Simanjiro, while crossbreeds were prevalent in the Kitengela plains.

\section{Discussion}

The results show that the overall livestock mortality rates varied among the four areas$14 \%$ in Simanjiro to 26\%,30\%, and 43\% in the Mara, Amboseli, and Kitengela-respectively (Figure 3 ). The available scientific literature lacks reference to overall multi-

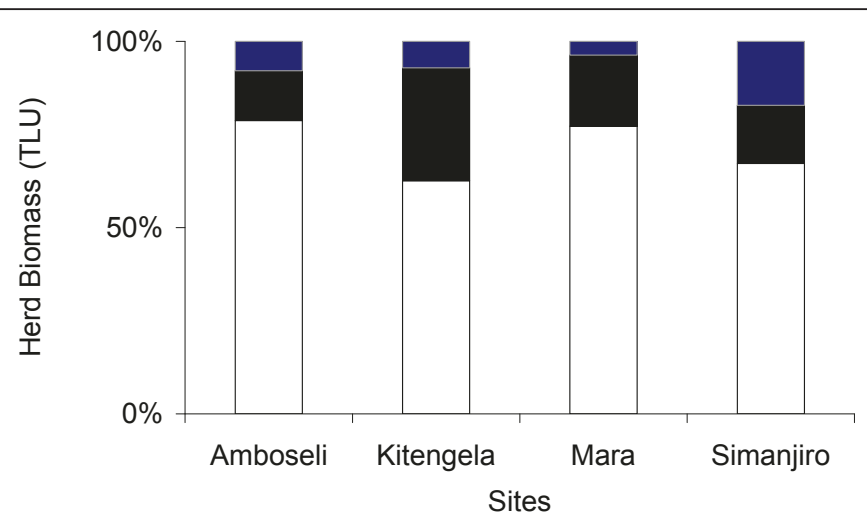

Figure 4 The proportional contribution of cattle, sheep (black), and goats (grey) to the total livestock biomass expressed in TLU. Total livestock biomass in 2005 by site. 
species herd mortality rates to compare our findings with. However, the observed mortality rates for cattle, which varied from $13 \%$ in Simanjiro to $29 \%, 32 \%$, and $45 \%$ in Maasai Mara, Amboseli, and Kitengela, respectively (Table 3), are higher than the mean rates of $8.3 \%$ reported for cattle in southern Kajiado in normal years (Bekure et al. 1991). Moreover, the mortality rates for cattle were slightly lower than those reported during previous droughts (Table 5), which were as high as $50-70 \%$ during the 1961 drought in Kajiado District (Willis 1999; Talbot 1972), 35-40\% during the 19731974 drought in Southern Kenya (Finch and Western 1977), 70-75\% in the Kitengela area during the 1974-1976 drought (Njoka 1979), and up to 50\% during the 2000 drought in Kajiado District (UNEP and GoK 2006). As cattle dominated herd biomass in all four areas, we thus conclude that the observed herd mortality rates were above what might be expected in a non-drought year (Figure 3).

Our data revealed a negative relation for three out of the four sites. The regression line in Figure 3 fitted through these three data points entered, when extrapolated to average or above normal rainfall conditions, the mortality zone which corresponds to non-drought years. However, the Kitengela plains, in spite of receiving normal to above normal rainfall, and contrary to expectation, had a much higher herd mortality rate of $43 \%$ (Figure 3). These surprising results indicate that differences in rainfall alone do not explain the variation in herd mortality between the sites.

There are two principal factors that might explain the unexpected high overall mortality in the Kitengela area. Firstly, as already explained, in 2004 large numbers of livestock migrated into Kitengela from the south-east (Kifugo et al. 2009; Mworia and Kinyamario 2008). This inward migration was caused by a pronounced lack of rainfall in the south-eastern rangelands (Figure 1). Knowing the Kitengela as a reliable drought refuge, and hearing that the Kitengela plains had received relatively good rains, pastoralists from as far as Mashuuru and Sultan Hamud (see Figure 1) drove their herds up north in anticipation of greener pastures. Such migration of livestock towards the wetter Kitengela plains has been common during past droughts (Njoka 1979; Casebeer and Mbai 1974).

This migration from the south increased stocking density in the Kitengela plains. We did not record the numbers of immigrant livestock, but based on our frequent visits and discussions with herdsmen and livestock owners, we estimated that stocking density was more than doubled. This high stocking density must have led to heightened competition for forage, as there was little left by the end of July 2005, which is abnormal in Kitengela during a normal rainfall year as was the case in 2005 . We suggest that this shortage of forage and water brought about by immigrant livestock induced the high starvation of the resident livestock. In addition, the fragmentation and inaccessibility of previously available pastureland in the Kitengela plains and year-round heavy grazing by livestock due to sedentarization probably also contributed to the higher mortality.

Secondly, the particular breeds in the Kitengela plains might form an additional explanation for the higher mortality rates. The Kitengela pastoralists have responded to the demand for meat and milk from nearby the Nairobi city by selecting high-yielding animal breeds. However, high-yielding cattle (Boran and Sahiwal crossbreeds) and sheep (mainly Dorper) breeds (Table 2) are less drought resistant (Degen et al. 2001). 
Table 5 Comparison of livestock mortality rates reported in this study with those reported for earlier droughts

\begin{tabular}{|c|c|c|c|c|c|}
\hline Area & Cattle(\%) & Shoats(\%) & Combined TLU (\%) & Drought year & Author (s) \\
\hline Amboseli & 32 & 26 & 30 & 2005 & This study \\
\hline Kitengela & 45 & 44.5 & 43 & & This study \\
\hline Maasai Mara & 29 & 21 & 26 & & This study \\
\hline Simanjiro & 13 & 17 & 14 & & This study \\
\hline Kajiado District & 50 & 20 & - & 2000 & UNEP and GoK \\
\hline Kaputiei South & $8-29$ & 50 & - & 1976 & (Bekure 1991) \\
\hline Kaputiei North and Central & $70-75$ & 36 & - & 1976 & (Njoka 1979) \\
\hline Kajiado & 70 & - & - & 1961 & (Talbot 1972) \\
\hline Kajiado & $13-15$ & - & - & 1927 & $\left(\right.$ Sindiga 1984) ${ }^{a}$ \\
\hline Narok & $30^{\mathrm{b}}$ & - & - & 1927 & (Sindiga, 1984) \\
\hline Turkana District & 63 & 55 & $50-70$ & $1979-80$ & (Ellis and Swift 1988; McCabe 1987) \\
\hline Kenya & - & - & $50-69$ & 1982-84 & $\begin{array}{l}\text { (Homewood and Lewis 1987); } \\
\text { (Oba 2001; Bollig 2006). }\end{array}$ \\
\hline Northern Kenya & - & - & $50-86$ & 1991-92 & (Angassa and Oba 2007; Oba 2001); \\
\hline Samburu; Northern Kenya & - & - & $40-50$ & 1997-98 & (FAO 2009; Little et al. 2001) \\
\hline
\end{tabular}

A comparison of livestock mortality rates reported in this study with mortality rates reported for earlier droughts in different parts of Maasailand. ${ }^{a}$ Source: MAR 1927 , cited in (Sindiga 1984$) .{ }^{b}$ Not clear whether the last three figures pertain to cattle or livestock in general. 
Are there any other contrasts between Kitengela and the three other areas that might explain the differences in mortality rates? Due to its proximity to Nairobi, the human population pressure has resulted in a continuous influx of people, growing land use changes, and fragmentation of lands. Since the 1990s pastoral lands have increasingly been fenced and converted to other land uses, thus restricting the mobility of wildlife and livestock (Reid et al. 2008; Kimani and Pickard 1998; Rutten 1992). Unpublished ILRI maps (Kifugo et al. 2009) reveal that by 2004, $16 \%$ of the Kitengela plains were inaccessible to mobile livestock because of fences. Longer grazing orbits imposed by the fences could have contributed to mortality by increasing energy demands, hence fencing likely amplified the higher mortality rates.

Hence, we attribute the unexpectedly higher livestock mortality in Kitengela to the prevalence of crossbred livestock and shortage of forage, which was not caused by drought in the Kitengela plains but by the influx of livestock responding to drought elsewhere. We postulate that the immigration of animals from drought-stricken areas to the south caused a forage and water shortage leading to the otherwise unexpected higher mortality rates in Kitengela. In addition, the crossbred livestock in Kitengela were likely more vulnerable to forage loss and diseases. This explanation, which appears plausible given the available evidence, questions the widely held opinion that pastoral mobility is positive because it enables pastoralists to sustain their herds, by migrating to areas that received more rainfall.

Nevertheless, the general view that pastoral mobility is a coping mechanism that allows pastoralists to preserve their animals may be true now as in the past. However, in the past, rangelands were underutilized and competition for forage resources less intense. In recent times, competition for resources is intensifying as demographic and other pressures as well as fragmentation and intensification of land use due to sedentarization progressively exclude pastoral livestock from their historical dry-season refuges. Our observations in Kitengela indicate that generalizations based on past experience may no longer be sufficient. During this particular drought, the immigration of animals from outside contributed to the mortality of the resident livestock. The influx of livestock into the Kitengela plains and the higher mortality consequently caused significant financial losses to the resident pastoral households in Kitengela (Table 3).

The argument in favour of pastoral mobility is that it is good for those who migrate from drought-stricken pastures to areas with more rainfall. Since these movements are often reciprocal, those receiving such herds also benefit in the future. We did not record mortality among the immigrant herds entering the Kitengela in 2005. We assume though, that the mortality rate among these herds must have been high as well, for the following reasons. Firstly, it is likely that by the time the decision was taken to move to Kitengela, the herds coming from outside were already in a worse condition than the resident livestock. Secondly, covering the long distance to Kitengela must have further worsened their condition. Hence, by the time they arrived in Kitengela, the conditions of the immigrant livestock must have been poorer than those of the resident livestock. We therefore suggest that the immigrant livestock may well have suffered similar or higher mortality than the resident livestock population. We caution, however, that this one-off experience may not suffice to water down the benefits of mobility in coping with spatial and temporal variability in rainfall, hence 
additional analyses would be required to evaluate the robustness and generality of our inference.

The relevant question in the context of the mobility benefit hypothesis is however whether mortality among the immigrant herds would have been lower if they would have stayed in their area of origin. Our data does not allow us to address that question. The recollection of our impressions during the surveys in the Kitengela is that immigrant livestock was in a worse condition and died in larger numbers.

Our observed livestock mortality rates thus suggest that pastoral mobility during this particular drought had negative impacts on the livelihoods of the resident pastoral households. The above arguments, furthermore, suggest that mobility may not have brought the herdsmen from outside what they had expected to find in Kitengela-a refuge to enable their livestock overcome the drought. However, from the immigrant point of view, the movement into Kitengela was a rational "honey-pot" effect-driven decision, that was definitely harmful for the resident population during that drought. In the end, for the immigrant households the movement into Kitengela complicated the situation by postponing death of their livestock, while leading them into a deathtrap.

Our analysis suggests that pastoral mobility may no longer be a panacea, especially for resident populations mainly composed of improved breeds and in fragmented and settled areas. An important question is whether the situation described here is generic and likely to be valid for many places and many droughts. We consider that events similar to those described for the Kitengela area will occur, in particular when drought affects all but a few isolated areas. In such cases pastoralists move to places at higher elevation, like the Kitengela plains, which on average, receives higher rainfall than the lands to its south. The Mara, Amboseli, and Simanjiro areas also have similar higher elevation drought reserves, parts of which have been converted to agriculture, but which functioned historically as important drought refuges. Under these circumstances, mobility will tend to concentrate animals towards small spots of green pasture. These may become "graveyards" rather than refuges when abnormally high numbers of animals compete for the limited resources.

Mobility is likely to be more beneficial when drought is restricted to smaller pockets surrounded by larger areas of adequate pasture. We suggest that under the current situation of intensive range utilization, the benefits of pastoral mobility depend on the intensity of the competition between resident and immigrant livestock that depends, in turn, on the relative availability of productive versus drought-stricken rangeland. The higher the ratio, the lower the concentration of livestock and the more likely that pastoral mobility will be beneficial, at least for the immigrants.

The introduction of high-yielding breeds in areas open to pastoral mobility poses a significant dilemma to pastoralists. Higher-yielding breeds and crossbreeds are attractive as they increase revenue from sales (Radeny et al. 2007; Degen et al. 2001). Yet, the downside is an increased vulnerability under stressful and low management conditions where forage is inadequate (Baker 1997). Our results and arguments above suggest that the more sensitive high-yielding breeds might suffer more from immigrant livestock depleting the forage resources, which they require to get through a drought. We question whether with these experiences pastoralists will continue to prefer higher-yielding breeds in areas of communal access. We argue that unless these 
livestock keepers can access relevant and timely information on these breeds, the costs of raising them may outweigh the benefits, especially in times of pasture scarcity and given the trend towards increasing frequency and severity of droughts.

The pattern described in this paper is not unique to the 2005-2006 drought and the Kitengela region. Essentially, the same story repeated itself in Kajiado during the drought of 2009 http://www.nation.co.ke/News/-/1056/661984/-/item/0/-/5sed4fz/-/ index.htm, with even more catastrophic outcome. Thus, the only key difference was that the herd mortality rates among immigrant livestock and the social impacts, which we will describe in a sequel to this paper, have been much more extreme as the drought was the worst recorded in the past 40 years (Western 2009); http://www. nation.co.ke/magazines/artandculture/-/1222/1222/-/to1b2g/-/index.html). Together, these findings suggest that it is time to highlight the benefits of providing relevant and timely information to support sustainable rearing of improved breeds in areas of common pool resources. Finally, policies that discourage land fragmentation and intensification of land use in pastoral rangelands should be prioritized to promote the resilience of pastoral livestock production systems to recurrent climatic extremes linked to global climate warming.

\section{Acknowledgements}

The data for this paper were collected with support from the Belgian-funded DGIC grant through the Reto-o-Reto project at the International Livestock Research Institute (ILRI). Fieldwork support from Moses Ole Nesselle and Leonard Onetu is highly appreciated. Thanks also to Jane Gitau and other members of the PLE-2 team for comments and suggestions that helped improve earlier drafts of this paper.

\section{Author details}

${ }^{1}$ International Livestock Research Institute, P.O. Box 30709 00100, Nairobi, Kenya ${ }^{2}$ The University of Edinburgh, School of Geosciences, Centre for the Study of Environmental Change and Sustainability, West Mains Road, King's Buildings, Edinburgh EH9 3JN, UK ${ }^{3}$ University of Hohenheim, Institute of Crop Science, Bioinformatics Unit, 70599 Stuttgart, Germany ${ }^{4}$ The University of Southampton, School of Management, Centre for Risk Research, Southampton, UK ${ }^{5}$ Center for Collaborative Conservation, 1401 Campus Delivery, Colorado State University, Fort Collins, CO 80523, USA

\section{Authors' contributions}

DN collected the data, took part in the analysis and led the writing of the paper; JO and MS took part in data analysis, writing, and generation of some graphs; $J$ contributed to the analysis, writing, and editing; RR edited the paper; TS provided data on droughts in northern Kenya; SK led the map-making exercise; DK helped with data collection and editing.

\section{Competing interests}

The authors declare that they have no competing interests.

Received: 16 February 2011 Accepted: 20 October 2011 Published: 20 October 2011

\section{References}

Angassa, A, and G Oba. 2007. Relating long-term rainfall variability to cattle population dynamics in communal rangelands and a governemnt ranch in southern Ethiopia. Agricultural Systems 94(3):715-25. doi:10.1016/.jagsy.2007.02.012.

Baker, RL. 1997. Genetic resistance to helminths in small ruminants in Africa. INRA Production Animales 10(1):99-110.

Behnke, RHJ. 2008. The Drivers of Fragmentation in Arid and Semi-Arid Landscapes. In Fragmentation in Semi-Arid and Arid Landscapes: Consequences for Human and Natural Systems, ed. Galvin Kathleen A, Reid RS, Behnke RHJ, Hobbs NT 13:305-340. Dordrecht, The Netherlands: Springer.

Bekure S, PN De Leeuw, BE Grandin, and PJH Neate. 1991. The Long-term productivity of the Maasai Livestock production system. In Maasai Herding: An Analysis of the Livestock Production System of the Maasai Pastoralists in Eastern Kajiado, Kenya, ed. S Bekure, De Leeu P.N, Grandin B.E., PJH Neate, Chapter Ten: Addis Ababa, Ethiopia: ILCA.

BibleGateway. 2009. Genesis. NIV. 47:1-4 http://www.biblegateway.com/passage/?search=Genesis+47\&version=NIV[NIV]. Ref Type: Electronic Citation.

Bollig, M. 2006. Risk Management in a hazardous environment: a comparative study of two pastoral societies. New York: Springer Verlag.

Borjeson, L, DL Hodgson, and ZY Pius. 2008. Northeast Tanzania's disappearing rangelands: Historical perspectives on recent land use change. International Journal of African Historical Studies 41(3):523-60.

Brockington, D. 2005. The contingency of community conservation. In Rural resources \& local livelihoods in Africa, ed. Homewood K 5:100-120. Oxford: James Currey Ltd. 
Campbell, DJ. 1999. Response to drought among farmers and herders in Southern Kajiado District, Kenya: A comparison of 1972-1976 and 1994-1995. Human Ecology 27(3):377-416. doi:10.1023/A:1018789623581.

Casebeer, RL, and HTM Mbai. 1974. Animal mortality-1973/74, Kajiado District. Rep. Project Working Paper No. 5, Kenya Game Department and UNDP/FAO Wildlife Management Project, Nairobi.

De Leeuw, PN. 1991. The study area: Biophysical environment. In Maasai herding: An analysis of the livestock producation system of Maasai pastoralists in Eastern Kajiado, Kenya, ed. Bekure S, De Leeu PN, Grandin BE, Neate PJH. Chapter Four: Addis Ababa: ILCA.

Degen, AA, A Nunow, AFM Zaal, DA Otieno, and JC Hoorweg. 2001. Market dependence of pastoralists in Kenya and Israel. Amsterdam: Royal Tropical Institute.

Ellis, J, and D Swift. 1988. Stability of African pastoral ecosystems: alternate paradigms and implications for development. Journal of Range Management 41:450-459. doi:10.2307/3899515.

FAO 2009. Reported drought occurrences in Africa 1910-2006.

Finch, VA, and D Western. 1977. Cattle colors in pastoral herds: Natural selection or social preference? Ecology 58(6):1384-92. doi:10.2307/1935090

Fratkin, E. 2001. East African pastoralism in transition: Maasai, Boran, and Rendille Cases. African Studies Review 44(3):1-25. doi:10.2307/525591.

Hardin, G. 1968. The tragedy of the commons. Science 162(13 December):1243-8.

Hodgson, DL. 2001. Once intrepid warriors: Gender, ethnicity, and the cultural politics of Maasai development. Bloomington and Indianapolis: Indiana University Press.

Homewood, K, PC Trench, and P Kristjanson. 2009. Staying Maasai? Pastoral livelihoods, diversification and the role of wildlife in development. In Staying Maasai? Livelihoods, conservation and development in East African Rangelands, ed. Homewood K, Pippa Chevenix Trench, Kristjanson P Ten:369-408. New York: Springer Science + Business Media, LLC

Homewood, K, and J Lewis. 1987. Impact of drought on pastoral livestock in Baringo, Kenya 1983-85. Journal of Applied Ecology 24(2):615-631. doi:10.2307/2403897.

Hughes, L. 2006. Moving the Maasai: A colonial misadventure Basingstoke, U.K.: Palgrave Macmillan.

Kenya Meteorological Department. Weather outlook for the March-May 2008 "Long-Rains" Season. The Standard, 30. 2008. Nairobi, Republic of Kenya. 3-14-2008. Ref Type: Newspaper.

Kifugo, S, C Bedelian, L Ng'ang'a, O Makui, and D Nkedianye, et al. 2009. Atlas on Counts of Livestock, Wildlife and People in Kitengela, 2009. International Livestock Rsearch Institute, ILRI, Nairobi.

Kimani, K, and J Pickard. 1998. Recent Trends and implications of group ranch sub-division and fragmentation in Kajiado, Kenya. The Geographical Journal 164(2):202-13. doi:10.2307/3060370.

Lamprey, HR, and RS Reid. 2004. Expansion of human settlement in Kenya's Maasai Mara: What future for pastoralism and wildlife? Journal of Biogeograpy 31:997-1032. doi:10.1111/j.1365-2699.2004.01062.x.

Le Houerou, HN. 1996. Climate change, drought and desertification: A review. Journal of Arid Environments 34:133-85. doi:10.1006/jare.1996.0099.

Little, P, H Mahmoud, and D Coppock. 2001. When deserts flood: risk management and climatic processes among East African pastoralists. Climate Research 19(2):149-59.

McCabe, J. 1987. Drought and recovery: livestock dynamics among the Ngisonyoka Turkana of Kenya. Human Ecology 15(4):371-89. doi:10.1007/BF00887997.

McCabe, TJ. 2003. Disequilibrial ecosystems and livelihood diversification among the Maasai of Northern Tanzania: Implications for conservation policy in East Africa. Nomadic Peoples 7(1):74-91. doi:10.3167/082279403782088921.

McPeak, J. 2005. Individual and collective rationality in pastoral production: Evidence from Northern Kenya. Human Ecology 33(2):171-97. doi:10.1007/s10745-005-2431-Y.

Mworia, JK, and JI Kinyamario. 2008. Traditional strategies used by pastoralists to cope with la nina induced drought in Kajiado, Kenya. African Journal of Environmental Science and Technology 2(1):10-4.

Njoka, T. 1979. Ecological and socio-cultural trends of Kaputiei Group Ranches in Kenya. PhD University of California, Bekerley.

Oba, G. 2001. The effect of multiple droughts on cattle in Obbu, Northern Kenya. Journal of Arid Environments 49(2):375-86. doi:10.1006/jare.2000.0785.

Oba, G, and WJ Lusigi. 1987. An overview of drought strategies and land use in African pastoral Systems. Pastoral Development Network Papers 23a.

Ogallo, LA, J Janowiak, and MS Halpert. 1988. Teleconnections between Rainfall over East Africa and Global Sea Surface Temperature Anomalies. Journal of Meteorological Society of Japan 66(6):807-22.

Ogutu, JO, HP Piepho, HT Dublin, N Bhola, and RS Reid. 2007. El Nino-Southern oscillation, rainfall, temperature and normalized difference vegetation index fluctuations in the Mara-Serengeti ecosystem. African Journal of Ecology 46(2):132-143.

Pratt, DJ, PJ Greenway, and MD Gwynne. 1966. A Classification of East African Rangelands. Journal of Applied Ecology 3:369-82. doi:10.2307/2401259.

Radeny, M, D Nkedianye, P Kristjanson, and M Herrero. 2007. Livelihood choices and returns among pastoralists: Evidence from Southern Kenya. Nomadic Peoples 11(2):31-55. doi:10.3167/np.2007.110203.

Reid, RS, H Gichohi, MY Said, D Nkedianye, and JO Ogutu, et al. 2008. Fragmentation of a peri-urban savanna, Athi-Kaputiei Plains, Kenya. In Fragmentation in semi-arid and arid landscapes: Consequences for human and natural systems, ed. Galvin Kathleen A, Reid RS, Behnke RHJ, Hobbs NT 9:195-224. Fort Collins: Springer.

Rutten, MMM. 1992. Selling wealth to buy poverty: the process of individualization of land ownership among the Maasai Pastoralists of Kajiado District, Kenya, 1890-1990. Fort Lauderdale: Vertag breitenbachs Publishers.

Sindiga, I. 1984. Land and population problems in Kajiado and Narok, Kenya. African Studies Review 27(1):23-39. doi:10.2307/ 523948.

Spencer, P. 1974. Drought and the commitment to growth. African Affairs 73(293):419-27.

Talbot, LM. 1972. Ecological consequences of rangeland development in Maasailand, East Africa. In The careless technology, ed. Farvar MT, Milton JP 37:695-711. New York: Doubleday.

UNEP GoK 2006. Kenya drought impacts on agriculture, livestock and wildlife. Nairobi: United Nations Environment Programme, pp. 1-81. 
Western, D. 2009. Drought devastating wildlife, cattle, and human lives. ACC. http://www.africanconservationfund.org/. Ref Type: Electronic Citation.

Willis, J. 1999. Enkurma Sikitoi: Commoditization, drink, and power among the Maasai. The International Journal of African Historical Studies 32(2/3):339-57. doi:10.2307/220345.

Zamani, GH, J Gorgievski-Duijvesteijn Marjan, and Zarafshani Kiumars. 2006. Coping with drought: towards a multilevel understanding based on conservation of resources theory. Human Ecology 34:677-92. doi:10.1007/s10745-006-9034-0.

doi:10.1186/2041-7136-1-17

Cite this article as: Nkedianye et al: Mobility and livestock mortality in communally used pastoral areas: the impact of the 2005-2006 drought on livestock mortality in Maasailand. Pastoralism: Research, Policy and Practice 2011 1:17.

\section{Submit your manuscript to a SpringerOpen ${ }^{\circ}$} journal and benefit from:

- Convenient online submission

- Rigorous peer review

- Immediate publication on acceptance

- Open access: articles freely available online

- High visibility within the field

- Retaining the copyright to your article

Submit your next manuscript at $\boldsymbol{\wedge}$ springeropen.com 